\title{
Screening and Isolation of Bacteria Producing Biosurfactants from Waste
}

\author{
Shaikh M. Shagufta (D) and P.V. Dharani* (D) \\ Department of Microbiology, Sheth P.T. Arts and Science College, \\ Shri Govind Guru University, Godhra - 389 001, Gujarat, India.
}

\begin{abstract}
Biosurfactant are surface active compounds (SAC), amphiphilic in nature consisting of hydrophobic (long chain fatty acids) and hydrophilic domain (amino acid, protein, carbohydrate). Classification of this compound is based on molecular weight, mode of action and physico-chemical structure. Biosurfactant are being utilized in laundry formulation, house hold cleaning products, as antimicrobial agents, in detergents, pesticides, food and pharmaceutical industries. Various type of microorganism has been studied capable of synthesizing wide range biosurfactant by utilizing hydrocarbon compounds as source of carbon and energy. Present study aims to isolate biosurfactant producing bacteria from different waste sources. In this study among twenty-one isolated microbial cultures from different waste samples were screened for biosurfactant production using methods like hemolytic activity, blue gar assay, hydrocarbon tolerance assay, oil spread test, Emulsification index (E24\%).
\end{abstract}

Keywords. Biosurfactant, Oil Spreading Method, Emulsification index, Modified Drop Collapse, Tolerance against Hydrocarbon, Hemolytic activity, Blue agar plate, Agar well diffusion

\footnotetext{
*Correspondence: prasannaaiyer30809@gmail.com

(Received: September 5, 2021; accepted: January 24, 2022)

Citation: Shagufta SM, Dharani PV. Screening and Isolation of Bacteria Producing Biosurfactants from Waste. J Pure App Microbiol. 2022;16(1):567-577. doi: 10.22207/JPAM.16.1.55

(C) The Author(s) 2022. Open Access. This article is distributed under the terms of the Creative Commons Attribution 4.0 International License which permits unrestricted use, sharing, distribution, and reproduction in any medium, provided you give appropriate credit to the original author(s) and the source, provide a link to the Creative Commons license, and indicate if changes were made.
} 


\section{INTRODUCTION}

Hydrocarbon compounds are widely used in vehicles are among the potential contaminant. Release of this contaminants to the environment and petroleum derived compound are major cause of contamination. Hydrocarbon molecule when released into environment cannot be removed easily, as they absorbs to the surfaces. Surfactant are chemical compounds, amphiphilic in nature, tend to accumulate at the interfaces between two liquid phases with different polarities (e.g., oil-water) and reduces surface tension. Most of surfactant are synthesized chemically, and are partially biodegradable, causing noxious effect on environment and human health. Some microorganism can degrade hydrocarbon by producing biosurfactant. Microbial surfactant is more effective and versatile than many synthetic chemical surfactant owing their potential action, are biodegradable, and stable at high temperature. The structure of biosurfactant includes mycolic acid, glycolipid, polysaccharide lipid complex, lipoprotein, lipopeptides, phospholipids and microbial cell surface itself. ${ }^{1}$ The application of biosurfactant ranges from agriculture to cosmetics; from food to petrochemical and from textiles to petroleum production, ${ }^{2,3}$ oil recovery; remediation of organic and metal contaminated sites. ${ }^{4}$

\section{MATERIALS AND METHODS Sample collection}

Four types of waste were collected. These were the water drained during washing of uncooked rice, water left after cooking of rice, water drained after boiling of corn and mixture of cooked rice water and boiled corn water. The samples were collected in glass bottles sterilized in hot air oven, at $170^{\circ} \mathrm{C}$ for 60 minutes. These samples were left at $30^{\circ} \mathrm{C}$ for 48 hours. After 48 hours, coconut oil parachute brand of Marico Limited, Mumbai, India)having saturated fatty acid $91 \mathrm{~g} / 200 \mathrm{ml}$ (in mixture and rice water), home made ghee from buffalo milk having $86.46 \mathrm{~g}$ saturated fatty acid, (in corn water), petrol obtained from nearby petrol pump containing paraffin $30 \%$, napthens $49 \%$, asphatic $6 \%$, aromatic compounds $15 \%$, respectively were added. After adding different hydrocarbons in all sample bottles, these were further incubated at room temperature for 6 days (Fig. 1).
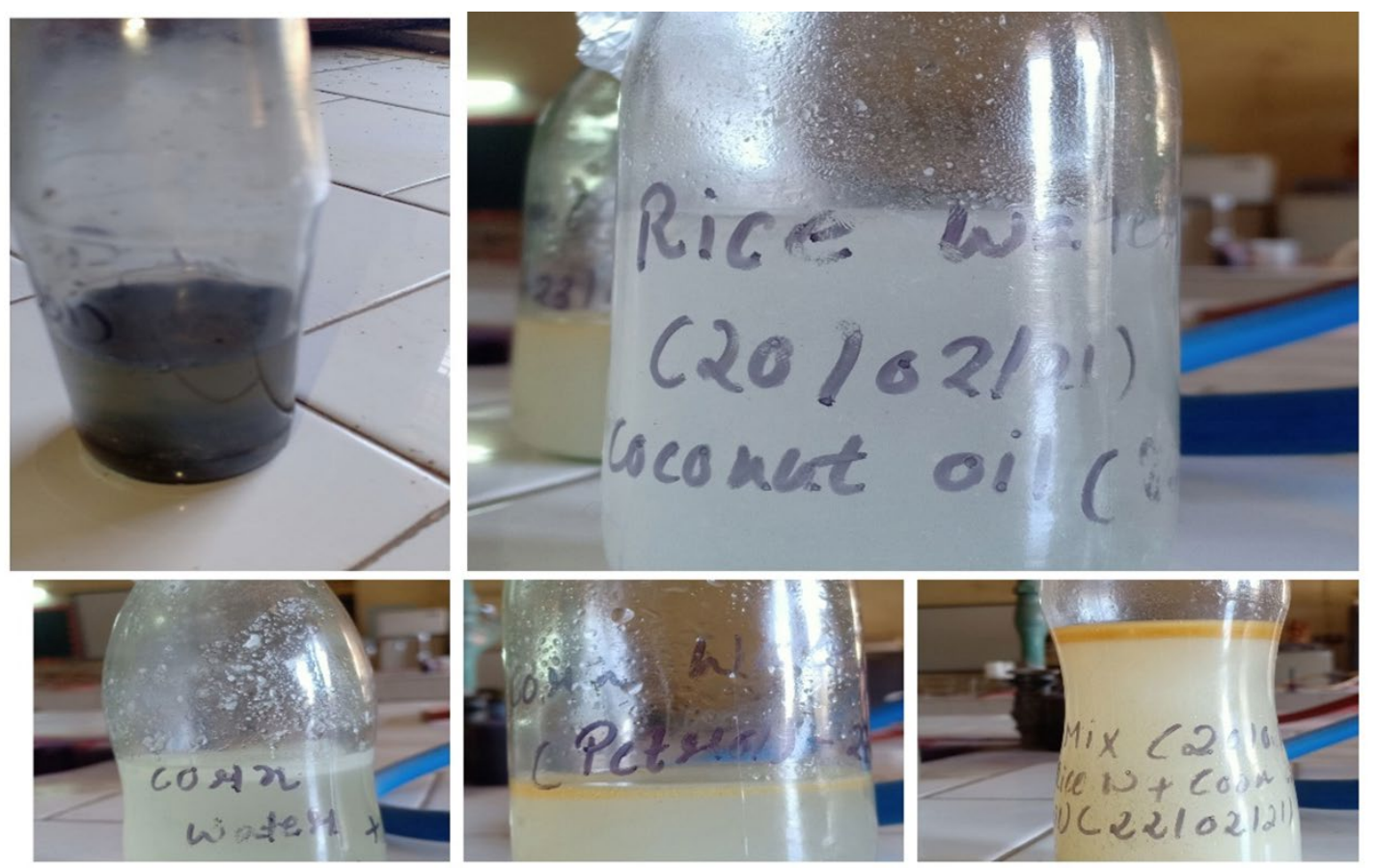

Fig. 1. Samples collected in glass bottles sterilized 


\section{Characterization of biosurfactant produced in waste}

Each sample after 6 days incubation were analyzed for production of biosurfactant by performing various tests as mentioned herewith.

\section{Oil Spreading Method (OSM)}

$10 \mathrm{ml}$ distilled water added to Petri dish. To this, paraffin oil containing $1 \mathrm{ml}$ of $0.5 \%$ Sudan black dye was added. This was followed by addition of 1 drop incubated sample onto paraffin surface. The incubated sample containing biosurfactant separated the Sudan black dye containing paraffin layer and formed a clear zone..$^{5,6}$ The same procedure was done with Vim liquid soap (Hindustan Unilever Limited, India) as a control. Vim liquid soap contains lauryl sulphate, disodium EDTA, lime juice, chlorine, water.

Emulsification index (EI24\%)

Equal volume of supernatant from incubated wastes and engine oil in one test tube (1:1), and equal volume of supernatant from incubated wastes and paraffin oil (1:1) were taken. Contents of each tube were thoroughly mixed for 2 minutes using vortex mixer. ${ }^{7,8}$ The contents in the tubes were then left to stand for 24 hours at $37^{\circ} \mathrm{C}$. The same test was performed with vim liquid soap as a control. After $24 \mathrm{~h}$, the emulsification activity was calculated using following formula:

E24 (\%) = total height of the emulsified layer/total height of the liquid layer.

Modified Drop Collapse (MDC) assay

Screening of biosurfactant production was performed using the qualitative drop-collapse test described by Bodour et al. ${ }^{9}$ and Jain et al. ${ }^{10}$ This assay relies on the destabilization of liquid droplets by surfactants. Engine oil $(80 \%$ base oil1-10\%, alkenyl succinic, 1-10\% salicylic acid, base oil-petroleum, poly alpha olifins) was applied as a coating, on glass plate. A drop of incubated sample was placed over it to analyze drop collapse. Vim liquid soap was used as control. ${ }^{11}$

Isolation of biosurfactant producing bacteria from the incubated samples by streak plate method

Incubated wastes samples that showed biosurfactant production were streaked on nutrient agar plate, followed by incubation of plate at $37^{\circ} \mathrm{C}$ for 24 hours.

Spot inoculation of isolated colonies to another nutrient agar plate

Isolated colonies from nutrient agar plates were spot inoculated on to a new nutrient agar plate. Which were then incubated at $37^{\circ} \mathrm{C}$ for 24 hours (Fig. 2).

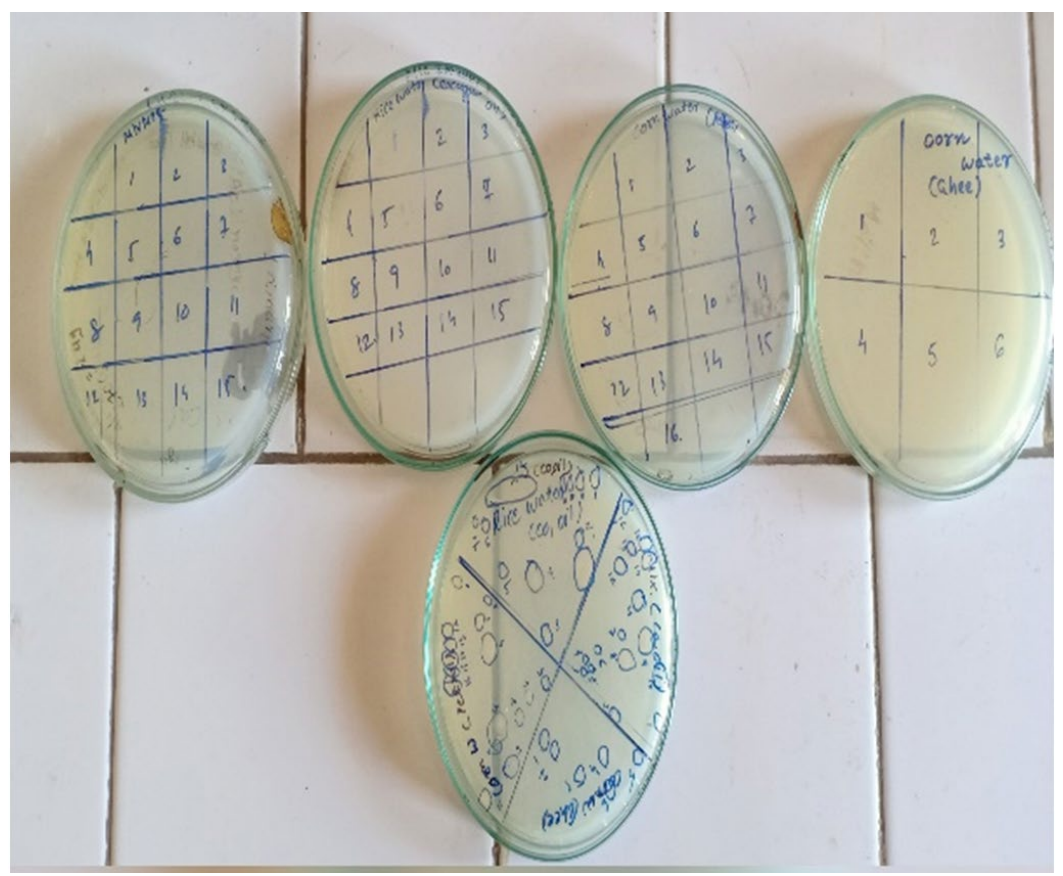

Fig. 2. Streak plate and spot inoculation. 


\section{Tolerance Against Hydrocarbon (TAH)}

In order to analyze the ability of isolate to grow in presence of hydrocarbon, nutrient agar plate having isolated colonies were coated with seed agar followed by spreading of engine oil over surface. The plates were then incubated at $37^{\circ} \mathrm{C}$ for 24-48 hours. Colony surrounded by emulsified halos was considered positive for biosurfactant production. Positive isolates were cultured in sterile medium containing tap water and engine oil as sole source of carbon.

\section{Hemolytic activity (HA)}

Isolated bacterial culture which were inoculated in the nutrient broth from broth and incubated for 4 hours at $37^{\circ} \mathrm{C}$ was streaked on sterile $5 \%$ blood agar plate and incubated at $37^{\circ} \mathrm{C}$ for 24 - 48 hours. Hemolytic activity was detected as the presence of a definite clear zone around a

Table 1. Modified Oil Spread (MOS) test

\begin{tabular}{lllllll}
\hline $\begin{array}{l}\text { Name of } \\
\text { the test }\end{array}$ & $\begin{array}{l}\text { Control } \\
\text { (VIM liquid } \\
\text { soap) }\end{array}$ & $\begin{array}{l}\text { Broth 1 } \\
\text { (Rice water + } \\
\text { coconut oil) }\end{array}$ & $\begin{array}{l}\text { Broth 2 } \\
\text { (Rice water+Corn } \\
\text { water+Coconut oil) }\end{array}$ & $\begin{array}{l}\text { Broth 3 } \\
\text { (Corn water } \\
\text { +ghee) }\end{array}$ & $\begin{array}{l}\text { Broth 4 } \\
\text { (corn water } \\
\text { + petrol) }\end{array}$ & $\begin{array}{l}\text { Broth 5 } \\
\text { (garage soil } \\
\text { + water) }\end{array}$ \\
\hline $\begin{array}{l}\text { Oil spread } \\
\text { test }\end{array}$ & $\begin{array}{l}\text { Oil drop } \\
\text { Completely } \\
\text { displaced at } \\
\text { edge }\end{array}$ & Negative & $\begin{array}{l}\text { Slight } \\
\text { displacement }\end{array}$ & $\begin{array}{l}\text { Oil drop } \\
\text { Completely } \\
\text { displaced at } \\
\text { edge. }\end{array}$ & Negative & $\begin{array}{l}\text { Slight } \\
\text { displacement } \\
\text { of oil drop. }\end{array}$ \\
\hline
\end{tabular}

Table 2. Emulsification index

\begin{tabular}{|c|c|c|c|c|c|c|}
\hline Name of the test & $\begin{array}{l}\text { Control } \\
\text { (VIM) }\end{array}$ & $\begin{array}{c}\text { Broth } 1 \\
\text { (Rice water } \\
+ \text { coconut oil) }\end{array}$ & $\begin{array}{c}\text { Broth } 2 \\
\text { Rice water+ } \\
\text { corn water+ } \\
\text { coconut oil) }\end{array}$ & $\begin{array}{c}\text { Broth } 3 \\
\text { (Corn water } \\
+ \text { ghee) }\end{array}$ & $\begin{array}{c}\text { Broth } 4 \\
\text { (corn } \\
\text { water }+ \\
\text { petrol) }\end{array}$ & $\begin{array}{c}\text { Broth } 5 \\
\text { (garage } \\
\text { soil + } \\
\text { water) }\end{array}$ \\
\hline $\begin{array}{l}\text { Emulsification index. } \\
\text { E24 with paraffin oil }\end{array}$ & pending & $2.94 \%$ & $3.33 \%$ & $16.66 \%$ & $6.98 \%$ & $20 \%$ \\
\hline E24 with servo engine oil & $42 \%$ & $46 \%$ & $57 \%$ & $48 \%$ & $51 \%$ & $40 \%$ \\
\hline \multicolumn{7}{|c|}{ Table 3. Modified Drop Collapse (MDC) test } \\
\hline Name of the test & $\begin{array}{l}\text { Control } \\
\text { (VIM) }\end{array}$ & $\begin{array}{c}\text { Broth } 1 \\
\text { (Rice water } \\
+ \text { coconut oil) }\end{array}$ & $\begin{array}{c}\text { Broth } 2 \\
\text { Rice water+ } \\
\text { corn water+ } \\
\text { coconut oil) }\end{array}$ & $\begin{array}{c}\text { Broth } 3 \\
\text { (Corn water } \\
+ \text { ghee) }\end{array}$ & $\begin{array}{l}\text { Broth } 4 \\
\text { (corn } \\
\text { water }+ \\
\text { petrol) }\end{array}$ & $\begin{array}{c}\text { Broth } 5 \\
\text { (garage } \\
\text { soil + } \\
\text { water) }\end{array}$ \\
\hline Drop collapse test.(Result) & + & - & + & +++ & ++ & + \\
\hline Diameter of collapsed drop. & $0.5 \mathrm{~cm}$ & - & $0.5 \mathrm{~cm}$ & $2 \mathrm{~cm}$ & $1.0 \mathrm{~cm}$ & $0.9 \mathrm{~cm}$ \\
\hline
\end{tabular}

Table 4. Colony characters of isolates on nutrient agar plate (rice water+coconut oil)

\begin{tabular}{|c|c|c|c|c|c|c|}
\hline Colony characters & Sector 1 & Sector 2 & Sector 3 & Sector 4 & Sector 5 & Sector 6 \\
\hline Size & Small & Small & Small & Large & Moderate & Large \\
\hline Shape & Round & Irregular & Round & Irregular & Irregular & Irregular \\
\hline Margin & Entire & Entire & Entire & Curly & Entire & Lobate \\
\hline Elevation & Flat & Flat & Flat & Flat & Raised & Flat \\
\hline Texture & Smooth & Smooth & Smooth & Rough & Rough & Rough \\
\hline Pigmentation & Colorless & Yellowish & Colorless & Colorless & Dull white & Colorless \\
\hline Opacity & Opaque & Opaque & Opaque & Opaque & Opaque & Opaque \\
\hline
\end{tabular}


colony. ${ }^{12-14}$ Gram staining performed from isolated colony from blood agar plate.

Blue agar plate (BAP) method

Mineral salt agar medium supplemented with engine oil $(2 \mathrm{ml})$. Wells were made using sterile cup borer on methylene blue agar plate which were loaded with broth inoculated with isolated bacterial culture and incubated for 4 hours at $37^{\circ} \mathrm{C}$. This was followed by incubation at $37^{\circ} \mathrm{C}$ for 24-48 hours. A dark blue halo zone around the wells with active culture was considered positive for anionic biosurfactant production.

\section{Agar well diffusion (AWD) assay}

The ionic property of cell bound biosurfactant producing strain was determine by using agar well diffusion method. Uniformly

Table 5. Colony characters of isolates on blue agar plate (rice water coconut oil+corn water)

\begin{tabular}{ll}
\hline Colony characters & Observation \\
\hline Size & Small \\
Shape & Round \\
Margin & Entire \\
Elevation & Flat \\
Texture & Dry \\
Color & Dark blue (indicates \\
& positive result) \\
Opacity & Opaque \\
\hline
\end{tabular}

spaced wells were made on soft agar (1g\% agar). One well was loaded with $0.5 \%$ cetylperidium chloride (control), second well loaded with vim liquid soap as a anionic control and the remaining wells were loaded with broth inoculated with isolated bacterial culture and incubated for 4 hours at $37^{\circ} \mathrm{C}$. These plates were incubated at $37^{\circ} \mathrm{C}$ and observed for precipitation

\section{Determination of anionic and cationic characteristics}

Anionic or cationic property of biosurfactant can be analyzed by using methylene blue and methyl orange. Where cationic surfactant can be analyzed by using methyl orange dye and anionic biosurfactant can be analyzed by using methylene blue dye. To perform this test about 1 $\mathrm{ml}$ of sample was taken in test tube followed by adding methylene blue in one tube to determine anionic characteristics and addition of methyl orange for cationic characteristics. Extracted with chloroform left for overnight. Observed for blue or yellow colour.

\section{RESULTS}

The results of each sample after 6 days incubation which were analyzed for production and characterization of biosurfactant are discussed here.

Table 6. Colony characters of isolates on nutrient agar plate (corn water +ghee)

\begin{tabular}{lcccccc}
\hline Colony characters & Sector 1 & Sector 2 & Sector 3 & Sector 4 & Sector 5 & Sector 6 \\
\hline Size & Moderate & Moderate & Moderate & Large & Moderate & Small \\
Shape & Irregular & Round & Round & Irregular & Round & Irregular \\
Margin & Lobate & Entire & Entire & Lobate & Entire & Entire \\
Elevation & Flat & Raised & Flat & Flat & Raised & Flat \\
Texture & Smooth & Smooth & Smooth & Rough & Smooth & Rough \\
Pigmentation & Colorless & Yellowish & Colorless & Colorless & Dull white & Colorless \\
Opacity & Opaque & Opaque & Opaque & Opaque & Opaque & Opaque \\
\hline
\end{tabular}

Table 7. Colony characters of isolates on nutrient agar plate (corn water +petrol)

\begin{tabular}{|c|c|c|c|c|}
\hline Colony characters & Sector 1 & Sector 2 & Sector 3 & Sector 4 \\
\hline Size & Small & Large & Large & Small \\
\hline Shape & Irregular & Irregular & Irregular & Round \\
\hline Margin & Entire & Filamentous & Lobate & Entire \\
\hline Elevation & Raised & Flat & Flat & Flat \\
\hline Texture & Smooth & Smooth & Smooth & Smooth \\
\hline Pigmentation & Yellowish & Off white & Colorless & Colorless \\
\hline Opacity & Opaque & Opaque & Opaque & Opaque \\
\hline
\end{tabular}




\section{Oil Spreading Method (OSM)}

The incubated sample containing biosurfactant separated the Sudan black dye containing paraffin layer and formed a clear zone.

Same result was observed with positive control (vim liquid soap). Results obtained with different samples are as shown in Table 1. Corn water along with ghee shows higher degree for oil displacement.

\section{Emulsification index}

Emulsification test of broth was performed with engine oil and paraffin oil. E24 obtained for each broth after 24 hour is using above formulaE24 $(\%)=$ total height of the emulsified layer/total height of the liquid layer (Table 2). Higher emulsification index was observed from broth of corn water with petrol for both servo engine oil and paraffin oil.

\section{Modified Drop Collapse (MDC) test}

Drop got collapsed after $1 \mathrm{~min}$ showing different diameter for each broth while water taken as control showed negative result. Results are shown in Table 3. Large diameter for oil drop collapse observed with broth containing corn water and petrol.

\section{Results of isolates producing biosurfactant}

Among 21 selected isolates obtained from different waste sources, 4 isolates showed positive result for hydrocarbon tolerance assay and 7 isolates exhibited hemolytic activity.
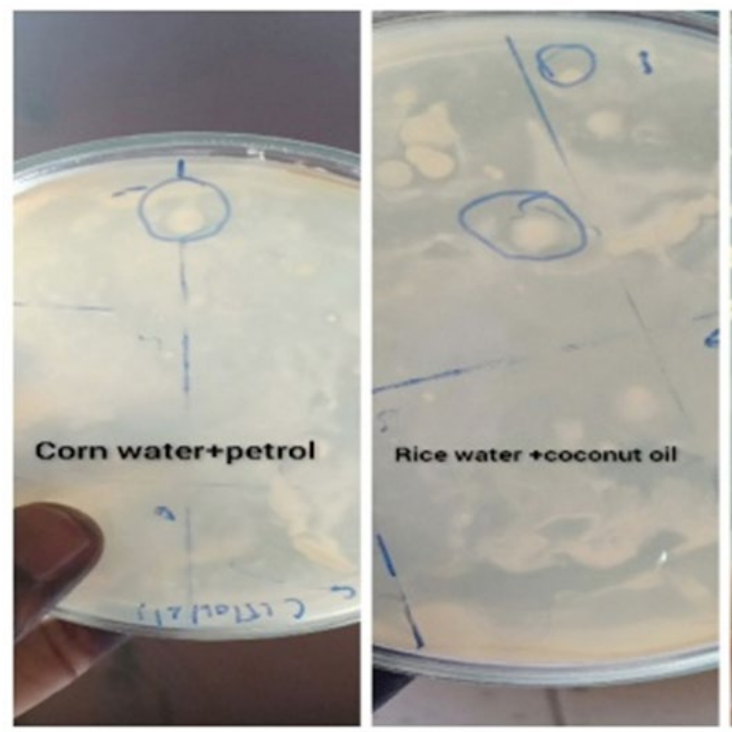

Fig. 3. Hydrocarbon tolerance assay.

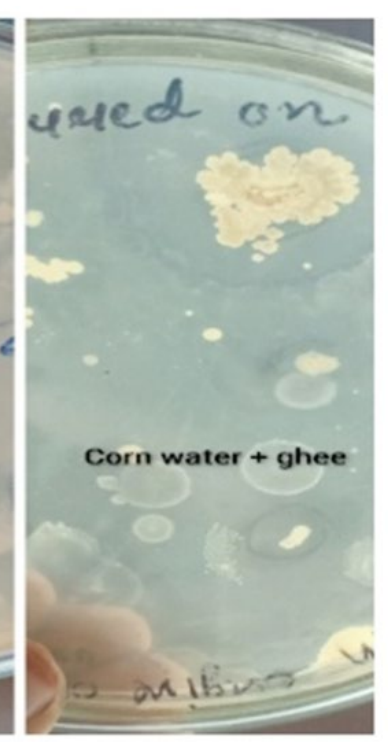

\section{Isolation by streak plate method}

Colonial morphology of all isolates was observed. 6 colonies observed on sector streaked with broth (corn water +ghee), 16 colonies observed on sector streaked with broth containing (corn water + petrol). 16 colonies observed on sector streaked with broth containing (Mix+ coconut oil). 15 colonies observed on sector streaked with broth containing (Rice water+ coconut oil).

\section{Spot inoculation of isolated colonies to another} nutrient agar plate

Colonial morphology of all isolates observed as shown in tables 4-7 and Fig. 2.

Tolerance Against Hydrocarbon (TAH)

Colony surrounded by emulsified halo was observed and selected for further work, inoculated in broth (distilled water and engine oil). Results for each broth are shown in Table 8. and Fig. 3.

\section{Hemolytic Activity}

Zone of hemolysis was observed with the various diameter. Hemolytic activity for each broth is along with colonial morphology and Gram staining Results of gram staining are illustrated in Table 9. Inoculated colonies utilized engine oil as carbon source, turbidity was observed over the surface of the each broth after 48 hours of incubation (Fig. 4). 


\section{Blue agar plate method}

Isolates produced dark blue halo around the well which was considered positive activity for biosurfactant production. Results for each broth is shown in Table 10 (Fig. 5).

\section{Agar well diffusion assay}

The taste is based on diffusion of two compounds bearing charges of the same or opposite type in a weakly concentrated gel, revealed precipitation lines between two compounds, no precipitation lines observed in any corresponding loaded well as shown in Table 11.

Determination of anionic and cationic characteristics

Test performed from each broth was observed for blue or yellow color after extraction with chloroform. Blue color was observed indicating anionic characteristics of isolated biosurfactant (Table 12).

\section{DISCUSSION}

Biosurfactant has wide range of application in remediation of hydrocarbons as they can intensify the growth of bacteria producing biosurfactant on hydrophobic surface and allow it to take nutrients from hydrophobic surface. In this project detail study was done on isolate from each collected sample. Waste used here are from corn and cooked rice. Corn contains higher amount of starch acts as good substrate for bacterial growth. ${ }^{15}$ Rice with close $\mathrm{pH}$ contains $79 \%$ carbohydrates, $7 \%$ protein, $2 \%$ fat plus vitamins and minerals, waste products of rice can act as excellent source of substrate for bacterial growth. Rodrigo et al. ${ }^{16}$ reported that oil spread technique is sensitive method for detection of small amount of biosurfactant produced. Here in oil spread assay in which sample 1 showed complete displacement of oil in edge indicating its greater potential to displace paraffin oil compared to other collected samples. Similar results were observed for modified drop collapse test. Upon screening among twenty-one cultures five isolates were able to tolerate hydrocarbons, in which all the isolates are Gram positive Bacillus. These isolates showed positive result for hydrocarbon tolerance while the same test was found to be negative for Bacillus with the hydrocarbon toluene 6. Hemolytic activity is used as preliminary test to describe biosurfactant production. Biosurfactant can lyse erythrocytes if biosurfactant is produced by organism. In this study, all the isolates produces zone of hemolysis with the size more than $2.30 \mathrm{~cm}$. Bacteria isolated from samples 1,2 and 3 showed more hemolytic activity compared to hemolytic activity of Bacillus culture that showed zone of hemolysis around 1.0 to 2.5 in the study performed by Thavasi et a ${ }^{17}$. Blue agar plate method results were found similar to activity by Pseudomonas. ${ }^{18}$ Potential activity for biosurfactant production by bacteria as can be determined by performing emulsification activity. Here emulsification activity was performed with three different hydrocarbons, servo engine oil, diesel and liquid paraffin. Highest emulsification was observed toward hydrocarbon servo engine oil which is high compared to the report of Nishanthi et al. ${ }^{19}$ The isolates obtained have shown promising results, so more studies
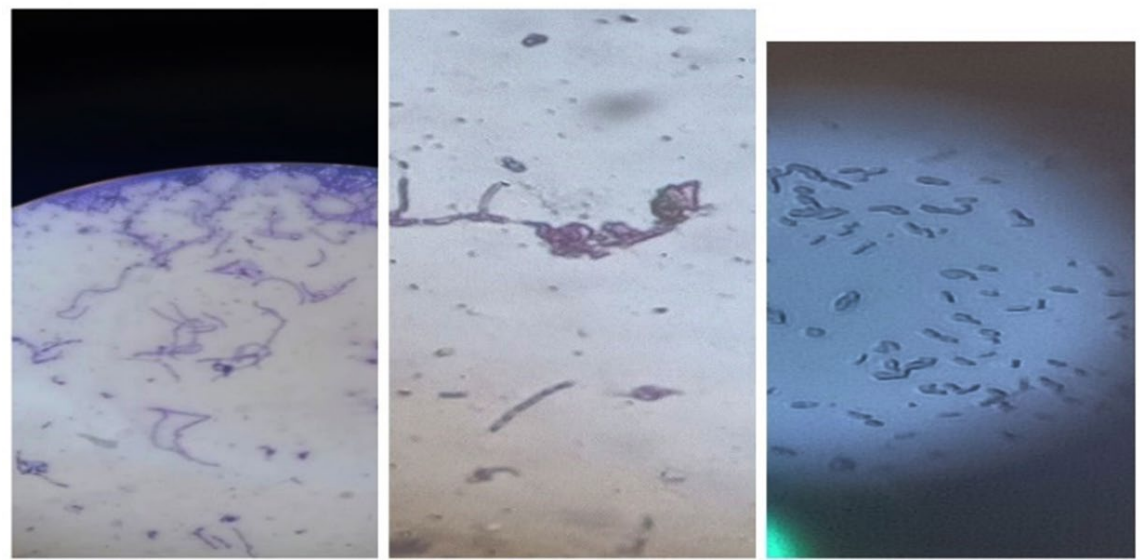

Fig. 4. Gram staining. 


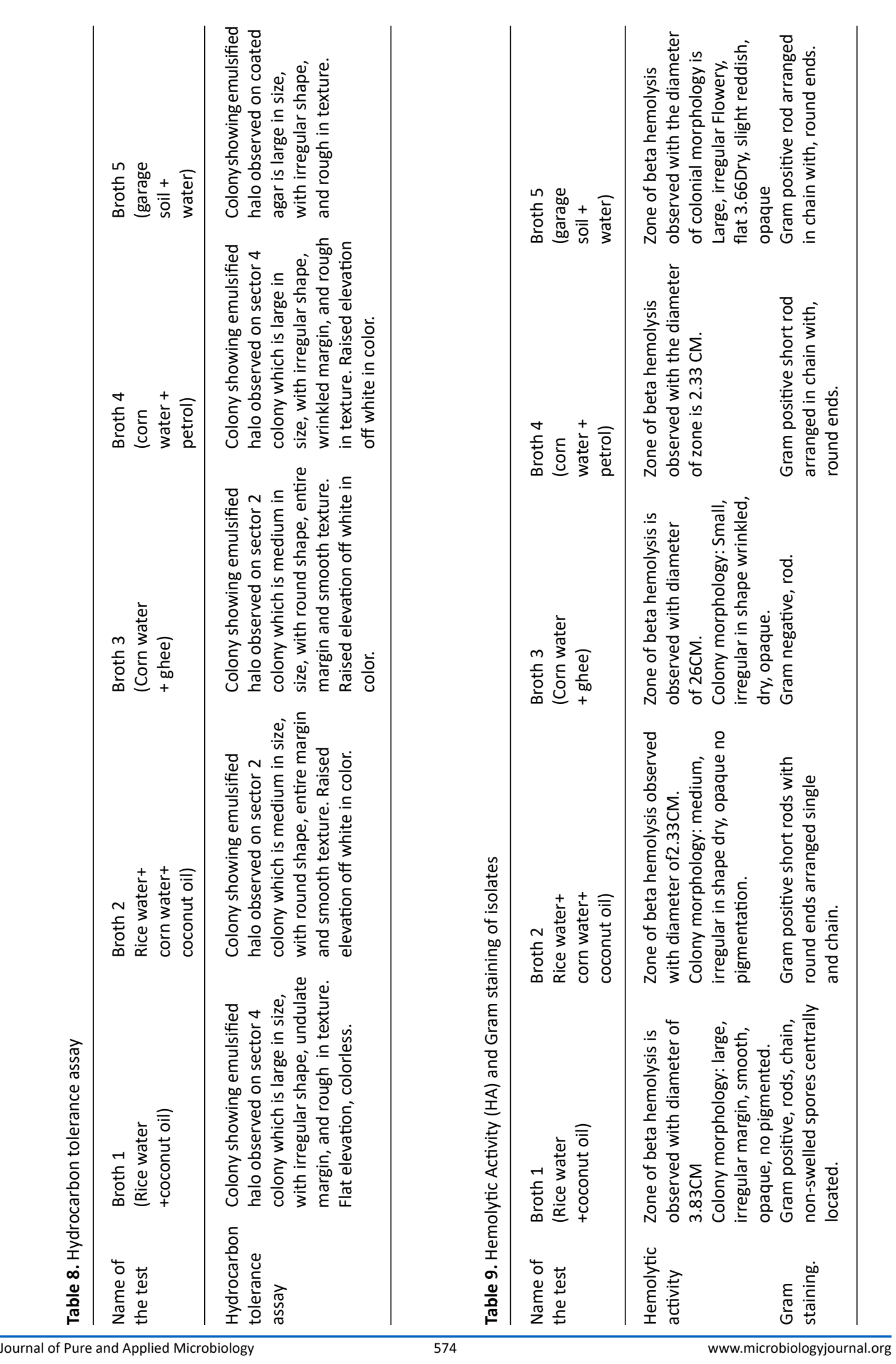


Table 10. Blue agar plate method

\begin{tabular}{|c|c|c|c|c|c|}
\hline $\begin{array}{l}\text { Name of } \\
\text { the test }\end{array}$ & $\begin{array}{l}\text { Broth } 1 \\
\text { (Rice water } \\
\text { +coconut oil) }\end{array}$ & $\begin{array}{l}\text { Broth } 2 \\
\text { (Rice water+ } \\
\text { corn water+ } \\
\text { coconut oil }\end{array}$ & $\begin{array}{l}\text { Broth } 3 \\
\text { (Corn water+ } \\
\text { ghee) }\end{array}$ & $\begin{array}{l}\text { Broth } 4 \\
\text { (Corn water }+ \\
\text { petrol) }\end{array}$ & $\begin{array}{l}\text { Broth } 5 \\
\text { (Garage soil + water) }\end{array}$ \\
\hline $\begin{array}{l}\text { Blue agar } \\
\text { plate } \\
\text { method. }\end{array}$ & $\begin{array}{l}\text { Positive. Well } \\
\text { surrounded by dark } \\
\text { blue color observed. }\end{array}$ & $\begin{array}{l}\text { Positive. Well } \\
\text { surrounded by } \\
\text { dark blue color } \\
\text { observed. }\end{array}$ & $\begin{array}{l}\text { Positive. Well } \\
\text { surrounded by } \\
\text { dark blue color } \\
\text { observed. }\end{array}$ & $\begin{array}{l}\text { Positive. Colony } \\
\text { surrounded by } \\
\text { dark blue colour } \\
\text { is observed. }\end{array}$ & $\begin{array}{l}\text { Positive. Well } \\
\text { surrounded by } \\
\text { dark blue color } \\
\text { observed }\end{array}$ \\
\hline \multicolumn{6}{|c|}{ Table 11. Agar well diffusion assay } \\
\hline $\begin{array}{l}\text { Name of } \\
\text { the test }\end{array}$ & $\begin{array}{l}\text { Broth } 1 \\
\text { (Rice water } \\
\text { +coconut oil) }\end{array}$ & $\begin{array}{l}\text { Broth } 2 \\
\text { (Rice water+ } \\
\text { corn water+ } \\
\text { coconut oil }\end{array}$ & $\begin{array}{l}\text { Broth } 3 \\
\text { (Corn water+ } \\
\text { ghee) }\end{array}$ & $\begin{array}{l}\text { Broth } 4 \\
\text { (Corn water }+ \\
\text { petrol) }\end{array}$ & $\begin{array}{l}\text { Broth } 5 \\
\text { (Garage soil + water) }\end{array}$ \\
\hline $\begin{array}{l}\text { Agar well } \\
\text { diffusion } \\
\text { assay }\end{array}$ & $\begin{array}{l}\text { No precipitation } \\
\text { line observed. }\end{array}$ & $\begin{array}{l}\text { No precipitation } \\
\text { line observed }\end{array}$ & $\begin{array}{l}\text { No precipitation } \\
\text { line observed }\end{array}$ & $\begin{array}{l}\text { No precipitation } \\
\text { line observed }\end{array}$ & $\begin{array}{l}\text { No precipitation } \\
\text { line observed }\end{array}$ \\
\hline
\end{tabular}

Table 12. Determination of anionic and cationic characteristics

\begin{tabular}{lccccccc}
\hline $\begin{array}{l}\text { Determination of } \\
\text { Anionic/Cationic } \\
\text { characteristics. }\end{array}$ & $\begin{array}{c}\text { Sodium } \\
\text { lauryl } \\
\text { sulphate. } \\
\text { (Anionic } \\
\text { standard) }\end{array}$ & $\begin{array}{c}\text { Cetyl } \\
\text { pyridinum } \\
\text { chloride. } \\
\text { (Cationic } \\
\text { standard) }\end{array}$ & Sample 1 & Sample 2 & Sample 3 & $\begin{array}{c}\text { Sample 4 } \\
\text { (Rice water + } \\
\text { coconut oil) }\end{array}$ & Sample 5 \\
\hline $\begin{array}{l}\text { Observation } \\
\text { Result }\end{array}$ & Blue & $\begin{array}{c}\text { Yellow } \\
\text { Cationic }\end{array}$ & $\begin{array}{c}\text { Blue } \\
\text { Anionic }\end{array}$ & $\begin{array}{c}\text { Blue } \\
\text { Anionic }\end{array}$ & $\begin{array}{c}\text { Blue } \\
\text { Anionic }\end{array}$ & $\begin{array}{c}\text { Blue } \\
\text { Anionic }\end{array}$ & $\begin{array}{c}\text { Blue } \\
\text { Anionic }\end{array}$ \\
\hline
\end{tabular}
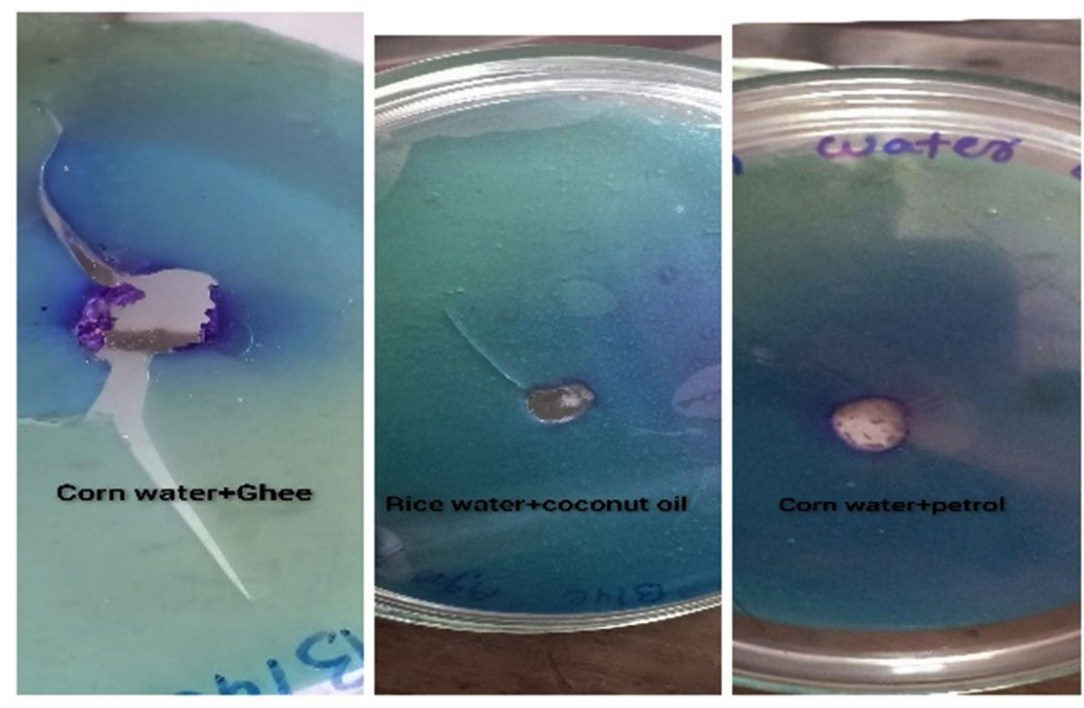

Fig. 5. Blue agar plate method. 
regarding the isolates and the biosurfactant produced would be taken up in future studies.

\section{CONCLUSION}

These tests provide rapid and easy screening of biosurfactant producing bacteria. Upon observation of results all isolates studied gives positive results for biosurfactant production. Among all studied bacterial cultures isolates from sample 1 shows highest potential for biosurfactant production followed by isolates of sample 3 . Among five isolated cultures, four cultures are gram positive one is gram negative having potential to produce biosurfactant can be used for biodegradation of hydrocarbons, and other industrial processes.

\section{ACKNOWLEDGMENTS}

None.

\section{CONFLICT OF INTEREST} conflict of interest.

The authors declare that there is no

\section{AUTHORS' CONTRIBUTION}

All authors listed have made a substantial, direct and intellectual contribution to the work, and approved it for publication.

\section{FUNDING}

This study was funded by Developing High Quality Research (SHODH) Scheme, Department of Education, Government Of Gujarat (KCG/ SHODH/2020-21/).

\section{DATA AVAILABILITY}

All datasets generated or analyzed during this study are included in the manuscript.

\section{ETHICS STATEMENT}

This article does not contain any studies with human participants or animals performed by any of the authors.

\section{REFERENCES}

1. Karanth NGK, Deo PG, Veenanadig NK. Microbial production of biosurfactants and their importance. Curr Sci. 1999;77(1):116-123.

2. Reiling HE, Thanei-wyss U, Guerra-santos LH, Hirt R, Kappel O, Fiechter. A. Pilot plant production of rhamnolipid biosurfactant by Pseudomonas aeruginosa. Appl Env Microbiol. 1986;51(5):985-989. doi: 10.1128/aem.51.5.985-989.1986

3. Ochsner AU, Koch AK, Fiechter A, Reiser J. Isolation and characterization of a regulatory gene affecting rhamonolipid biosurfactant synthesis in Pseudomonas aeruginosa. J Bacteriol. 1994;176(7):2004-2054. doi: 10.1128/jb.176.7.2044-2054.1994

4. Bodour AA, Dress KP, Maier RM. Distribution of biosurfactant- producing bacteria in undisturbed and contaminated arid southwestern soils. Appl Env Microbiol. 2003;69(6):3280-3287. doi: 10.1128/ AEM.69.6.3280-3287.2003

5. Morikawa M, Hirata Y, Imanaka T. Astudy on the structurefunction relationship of lipopeptide biosurfactants. Biochim Biophys Acta. 2000.1488(3):211-218. doi: 10.1016/S1388-1981(00)00124-4

6. Nayarisseri A, Singh P, Singh SK. Screening, isolation and characterization of biosurfactant producing Bacillus subtilis strain ANSKLAB03. Bioinformation. 2018;14(6):304-314. doi: 10.6026/97320630014304

7. Asif A, Hareem M, Chaudhary SN, Fatima W. Comparative Analysis of Biosurfactant Production Assays by Five Indigenous Oil Sludge Bacteria. Biologia Pakistan. 2017;63(2):205-209.

8. Batista SB, Mounteer AH, Amorim FR, T'otola MR. Isolation and characterization of biosurfactant/ bioemulsifier-producing bacteria from petroleum contaminated sites. Bioresour Technol. 2006;97(6):868875. doi: 10.1016/j.biortech.2005.04.020

9. Bodour AA, Miller-Maier RM. Application of a modified drop-collapse technique for surfactant quantitation and screening of biosurfactant-producing microorganisms. J Microbiol Methods. 1998;32(3):273280. doi: 10.1016/S0167-7012(98)00031-1

10. Jain DK, Collins-Thompson DL, Lee H, Trevors JT. A drop-collapsing test for screening surfactant-producing microorganisms, J Microbiol Methods. 1991;13(4):271279. doi: 10.1016/0167-7012(91)90064-W

11. Walter V, Syldatk C, Hausmann R. Screening Concepts for the Isolation of Biosurfactant Producing Microorganisms. Adv Exp Med Biol. 2010;672:1-13. doi: 10.1007/978-1-4419-5979-9_1

12. Carrillo PG, Mardaraz C, Pitta-Alvarez SI, Giulietti AM. Isolation and selection of biosurfactant-producing bacteria. World J Microbial Biotechnol. 1996;12(1):8284. doi: 10.1007/BF00327807

13. Mulligan CN, Cooper DG, Neufeld RJ. Selection of microbes producing biosurfactants in media without hydrocarbons. J Ferment Technol. 1984;62:311-314.

14. Rodrigues LR, Teixeira JA, van der Mei HC, Oliveira R. Isolation and partial characterization of a biosurfactant produced by Streptococcus thermophilus A. Colloids Surf B Biointerfaces. 2006;53(1):105-112. doi: 10.1016/j.colsurfb.2006.08.009

15. AjayiA O, Fagade OE. Utilization of corn starch as substrate for $\beta$ amylase by Bacillus spp. Afr J Biomed Res. 2003;6(1):37-42.

16. Rodrigo D, Rosell CM, Martinez A. Risk of Bacillus cereus in Relation to Rice and Derivatives. Foods.2021;10(2):302. doi: 10.3390/foods10020302 
17. Thavasi R, Sharma S, Jayalakshmi S. Evaluation of Screening Methods for the Isolation of Biosurfactant Producing Marine Bacteria. J Pet Environ Biotechnol. 2011;S1:001. doi: 10.4172/2157-7463.S1-001.

18. Hussain T, Khan AA. A combination of rapid and easy assays of bio surfactant producing bacterial strain isolated from automobiles repairing workshop in
Aligarh. Proceedings of the Voronezh State University of Engineering Technologies. 2018;80(3):153-163. doi: 10.20914/2310-1202-2018-3-153-163

19. Nishanthi R, Kumaran S, Palani P, Chellaram C, Anand TP, Kannan V. Screening of Biosurfactants from Hydrocarbon Degrading Bacteria. J Ecobiotechnol. 2010;2(5):47-53. 